\title{
Are fire temperatures and residence times good predictors of survival and regrowth for resprouters in Florida, USA, scrub?
}

\author{
Eric S. Menges ${ }^{1 *}$, Stacy A. Smith², Gretel L. Clarke ${ }^{1}$ and Stephanie M. Koontz ${ }^{1}$
}

\begin{abstract}
Background: Fire is a dominant ecological disturbance in many ecosystems. Post-fire resprouting is a widespread response to fire, but resprouting vigor varies with many components of the fire regime, including fire intensity. We measured responses in 46 species of resprouting plants of Florida, USA, scrub and related habitats, marking and measuring individual plants before fires. We then measured fire temperatures and residence times (time above $60^{\circ} \mathrm{C}$ ) during 13 fires, at the base of each plant. We measured post-fire plant sizes for up to six years. We hypothesized that high temperatures and long residence times would reduce survival and growth, and that these vital rates would vary by burn season, habitat type, and species group.

Results: Fires had variable intensities with maximum temperatures ranging from 47 to $890^{\circ} \mathrm{C}$ (mean temperature $=$ $549^{\circ} \mathrm{C}$ ) and residence times ranging from 0 to 83 minutes (mean time $=10$ minutes). Consumed plants experienced higher fire intensity than scorched plants, and residence times were higher during the wet season (July through October), than the dry season (November through April), and fire season (May to June) and with drier conditions. Across all species affected by fire, $86 \%$ of plants survived and resprouted post fire. First year survival was unrelated to fire variables, with high survival across all maximum temperatures and residence times. Burn season, habitat, and species group did not significantly affect survival. On average across all species, post-fire growth recovered to pre-fire heights within four years. Growth was not significantly affected by species group or burn season.

Conclusion: Resprouting perennial plants that dominate Florida scrub and surrounding habitats appear resilient to a wide range of fire intensities, as measured by maximum temperatures and residence times. Post-fire growth was rapid, with recovery of pre-fire heights in four years. Species groups varied in post-fire recovery rates. In these habitats, fire is critical to maintain the habitat structure for many animals and plants, including many rare species. The slower recovery of biomass for resprouting shrubs results in the longer availability of gaps for rare herbaceous species. In addition, variability in post-fire survival and growth among species groups likely contributes to the persistence of species diversity and complexity across habitats. However, variation in fire intensity appears to have little effect on resprouting species or subsequent habitat structure. A range of fire regimes can be used in prescribed fire management without having major impacts on resprouting plants in Florida scrub and related vegetation.
\end{abstract}

Keywords: fire intensity, fire management, flatwoods, post-fire growth, post-fire survival, resprouting, sandhill

\footnotetext{
* Correspondence: emenges@archbold-station.org

${ }^{1}$ Plant Ecology Program, Archbold Biological Station, 123 Main Drive, Venus,

Florida 33960, USA

Full list of author information is available at the end of the article
}

\section{Springer Open}

(c) The Author(s). 2021 Open Access This article is licensed under a Creative Commons Attribution 4.0 International License, which permits use, sharing, adaptation, distribution and reproduction in any medium or format, as long as you give appropriate credit to the original author(s) and the source, provide a link to the Creative Commons licence, and indicate if changes were made. The images or other third party material in this article are included in the article's Creative Commons licence, unless indicated otherwise in a credit line to the material. If material is not included in the article's Creative Commons licence and your intended use is not permitted by statutory regulation or exceeds the permitted use, you will need to obtain permission directly from the copyright holder. To view a copy of this licence, visit http://creativecommons.org/licenses/by/4.0/. 


\section{Resumen}

Antecedentes: El fuego es un disturbio ecológico dominante en muchos ecosistemas. El rebrote post-fuego es una respuesta amplia al fuego, aunque el vigor del rebrote varía con muchos componentes del régimen de fuego, incluyendo la severidad. Medimos la respuesta de 46 especies rebrotantes de Florida, EEUU, en arbustales y hábitats relacionados, marcando y midiendo plantas individuales antes de los fuegos. Medimos luego las temperaturas del fuego y su tiempo de residencia (tiempo por encima de los $60^{\circ} \mathrm{C}$ ) durante 13 fuegos, en la base de cada planta, y posteriormente medimos el tamaño de plantas por hasta seis años. Hipotetizamos que altas temperaturas y tiempos largos de residencia del fuego reducen la supervivencia y el crecimiento, y que esos atributos vitales podrían variar en función de la estación de quemas, el tipo de hábitat y el grupo de especies.

Resultados: Los fuegos tuvieron intensidades variables con temperaturas máximas ubicadas en un rango de entre 47 y $890^{\circ} \mathrm{C}$ (temperatura media $=549^{\circ} \mathrm{C}$ ) y tiempos de residencia de entre 0 y 83 minutos (tiempo medio $=$ 10 minutos). Las plantas consumidas por el fuego experimentaron una intensidad mayor que aquellas solo chamuscadas, y los tiempos de residencia fueron más altos durante la estación húmeda (julio a octubre), que en la estación seca (noviembre a abril) y en la estación de fuego (mayo a junio), y bajo condiciones más secas. Entre todas las especies afectadas por el fuego, $86 \%$ de las plantas sobrevivieron y rebrotaron. La sobrevivencia al primer año no fue relacionada con variables del fuego, con una alta supervivencia de aquellas que recibieron máximas temperaturas y tiempos de residencia. La supervivencia no fue afectada significativamente ni por la estación de quema, el hábitat, o los grupos de especies. En promedio y entre todas las especies, la recuperación del crecimiento a niveles de pre-fuego fue de cuatro años. El crecimiento no fue significativamente afectado por el grupo de especies o la estación de fuego.

Conclusiones: El rebrote de plantas perennes que dominan los arbustales y el hábitat que los rodean parecen ser resilientes a un amplio rango de intensidades de fuego, medido en función de las máximas temperaturas y tiempos de residencia del fuego. El recrecimiento post-fuego de los arbustos fue rápido, alcanzando alturas pre-fuego a los cuatro años. Los grupos de especies variaron en sus tasas de recuperación post-fuego. En estos hábitats, el fuego es crítico para mantener la estructura para varias plantas y animales, incluyendo especies raras. La lenta recuperación de la biomasa de arbustos rebrotantes resultó en una mayor disponibilidad de claros para el establecimiento de especies raras. Adicionalmente, la variabilidad en la supervivencia y crecimiento post-fuego entre grupos de especies probablemente contribuya a la persistencia de la diversidad y complejidad de especies entre hábitats. Sin embargo, la variación en la intensidad del fuego parece tener un efecto menor en las especies rebrotantes o en la subsecuente estructura del hábitat. Un rango de regímenes de fuego puede usarse en el manejo de quemas prescriptas sin tener mayores impactos en plantas rebrotantes de Florida y su vegetación relacionada.

\section{Abbreviations}

ABS: Archbold Biological Station

KBDI: Ketch-Byram Drought Index

RGR: Relative Growth Rate

\section{Background}

Disturbance regimes can affect plant vital rates and species distributions (Ehrlen and Morris 2015; QuintanaAscencio et al. 2018, 2019). Fire is the dominant ecological disturbance worldwide (Bond and Keeley 2005) and one that can be (partially) controlled by humans through fire suppression, prescribed burning, and vegetation manipulations (Guyette and Dey 2000; Archibald 2016). Fire regimes include variation in frequency (and time-since-fire), intensity (heat release), severity (impacts on ground and canopy), seasonality, patchiness, and ignition patterns (Keeley et al. 2011a). Fire regimes, drought, and other factors can affect the evolution of fire-related traits in plants such as germination cues, bark thickness, and resprouting (Keeley et al. 2011b; Lamont and He 2017).

Resprouting is a means by which plants regain biomass lost during disturbance (Bellingham and Sparrow 2000) and is a widespread adaptation allowing persistence in disturbed ecosystems (Bond and Midgley 2001). Resprouting can involve complex demographic tradeoffs (Bond and Midgley 2001; Maguire and Menges 2011) with resprouters often living longer, having slower growth, maturing later, and producing fewer seeds than non-resprouting species (Bond and Midgley 2001). Resprouting may occur from a variety of plant organs and originate either aboveground or belowground (Klimes and Klimes 2007). Successful resprouting depends on stored resources, thus diverting resources that could be invested in seed production (Bellingham and Sparrow 2000; Clarke et al. 2015).

Resprouting percentages vary across disturbance regimes (Vesk and Westoby 2004) and are often studied in 
relation to fire regimes (Pausas et al. 2018). With more intense fires, resprouting percentages are often bimodal (most species either rarely or commonly resprouting), but there may be a continuum of responses following less intense fire. Previous studies have shown resprouting percentages and vigor vary greatly depending on the species (Maguire and Menges 2011), fire regime (e.g. intensity, Moreno and Oechel 1991; season, Hmielowski et al. 2014), and environmental conditions (productivity, habitat, precipitation, and nutrients; Clarke et al. 2005).

Florida, USA, upland ecosystems such as Florida scrub, scrubby flatwoods, sandhill, and flatwoods habitats vary in their typical fire regime (Table 1). Generally, the natural fire frequency in these habitats ranges from 2 to 20 yr. Fires are typically of high intensity, but are often patchy. Florida experiences abundant lightning, which was likely responsible for most fire ignitions before European settlement (Duncan et al. 2010). The climate and vegetation chemistry suggest that high fire frequencies are possible in Florida (Guyette et al. 2012).

Seasonality of fire is a key factor in plant community responses to fire. The historical fire season in Florida scrub has been described as occurring in the spring transition between dry (winter) and wet (spring and summer) seasons, a period when fine fuels are driest and lighting events are increasing with the onset of summer storms (Platt et al. 2015). This transitional time is also a period between the dormant and growing season, when shrubs shift carbohydrates from belowground storage organs to aboveground stems, but when aboveground structures may have relatively low moisture content. Resprouting vigor is greater following fires in the dry, dormant season because energy reserves are stored safely belowground. Growing-season fires reduce shrub resprouting vigor as energy reserves are depleted with the consumption of aboveground stems (Willcox and Giuliano 2010; Robertson and Hmielowski 2014).

Plants of upland Florida ecosystems are well suited to respond to fire (Abrahamson 1984), either by resprouting (Olano et al. 2005), germinating from soil seed banks that respond to post-fire conditions (Ostertag and Menges 1994), or releasing seeds from serotinous cones after fires (Menges and Kohfeldt 1995; Peeler and
Menges 2018). Some types of Florida scrub (e.g., rosemary scrub) are dominated by reseeding species, while others (e.g., scrubby flatwoods) are dominated by resprouting shrubs (Menges and Kohfeldt 1995). In Florida scrub, dominant shrub species have high root to shoot ratios (oaks, Quercus spp., 2:1; saw palmetto, Serenoa repens, 7:1 [nomenclature follows Wunderlin et al. 2020]), allowing for strong resprouting (Johnson and Abrahamson 1990; Menges and Kohfeldt 1995; Saha et al. 2010). Many herbaceous species also resprout in response to fire (Menges and Kohfeldt 1995; Weekley and Menges 2003). However, individual species differ in resprouting response post fire (Maguire and Menges 2011); therefore, a variable fire regime is necessary to maximize biodiversity in Florida scrub (Menges 2007).

The goal of this project was to quantify survival and subsequent growth of common resprouting Florida scrub species following prescribed fire. Factors examined included fire intensity (temperature and residence times), habitat type, species groups, and burn seasons. We hypothesized that survival and regrowth of resprouting plants would:

1. be lower in plants exposed to higher temperatures and longer residence times;

2. vary by habitat, being lowest in drier habitats;

3. vary among species groups, with survival being higher and growth being lower for species of larger size; and

4. vary among burn seasons, with lower survival and growth for fires outside of the fire season.

\section{Methods}

\section{Study site and species}

This study was conducted in south-central Florida, USA, at Archbold Biological Station (ABS; Swain 1998; latitude: $27.17^{\circ} \mathrm{N}$, longitude: $\left.81.35^{\circ} \mathrm{W}\right)$. $\mathrm{ABS}$ is one of the largest remaining protected tracts on Lake Wales Ridge (Weekley et al. 2008), which is a hotspot for plant endemism (Estill and Cruzan 2001; Turner et al. 2006). ABS includes over 2100 ha of natural habitats, including Florida scrub, southern ridge sandhill, flatwoods, and seasonal ponds (Abrahamson et al. 1984). ABS is

Table 1 Natural fire-return intervals, dominant vegetation, and typical fire intensities for resprouting vegetation, defined by Menges (2007), of the Florida vegetation habitat following 13 prescribed fires, from 2006 to 2010, at Archbold Biological Station, Venus, Florida, USA. Peak fire season is in late spring (May through June) for all habitats. See Additional file 1 for complete identification of all species

\begin{tabular}{llll}
\hline Habitat & Fire-return interval $(\mathbf{y r})$ & Dominant vegetation & Typical fire intensity \\
\hline Scrubby flatwoods & 6 to 19 & Oaks, palmettos & High \\
Sand pine-oak scrub & 10 to 19 & Oaks, hickory, sand pine & High \\
Flatwoods & 6 to 9 & Palmettos, wiregrass, gallberry & Variable, often high \\
Southern ridge sandhill & 2 to 5 & Pines, wiregrass & Variable, often low \\
\hline
\end{tabular}


managed using a prescribed fire plan centered around modal fire-return intervals and emphasizing pyrodiversity, research, and safety (Menges et al. 2017a).

Florida scrub and scrubby flatwoods (the latter considered by the authors as a type of Florida scrub) are shrub-dominated systems characterized by resprouting species (Menges and Kohfeldt 1995; Menges 1999, 2007; Table 1). Sandhill vegetation at ABS (southern ridge sandhill; Abrahamson et al. 1984) has a mixture of grasses, shrubs, and herbs that are mainly resprouters (Reinhart and Menges 2004). Flatwoods vegetation is variably dominated by shrubs and grasses, most of which resprout after fire (Maliakal et al. 2000).

\section{Experimental design and field measurements}

We randomly established $1360 \mathrm{~m}$ transects in each of 13 management units slated for burning. Each transect was located in a single habitat type. Transects were located at least $10 \mathrm{~m}$ from fire lanes, roads, or other human-created features. We then used stratified random selection to select individual plants of each resprouting species present, one per $5 \mathrm{~m}$ along the transect and within $1 \mathrm{~m}$ of the transect (if a plant was available). Selected plants were marked with an aluminum tag secured to a stake flag. Since most resprouting species are clonal, we defined an individual as a group of stems, or clump of graminoids, within $15 \mathrm{~cm}$ of each other. On each transect, we aimed for five to ten replicates per species, for a maximum of 60 plants per transect.

For each plant, we measured standing height, maximum crown length and perpendicular width (all to the nearest centimeter), and counted the number of stems or clumps. We collected these data prior to a fire, six months post fire, and then annually for up to six years thereafter.

On the day of the fire, we confirmed that marked plants were still alive. We calculated the Ketch-Byram Drought Index (KBDI; Keetch and Byram 1968) using weather data collected at ABS. Fire temperatures were recorded with HOBO temperature dataloggers (Type $\mathrm{K}$ thermocouple logger part H12002; Onset Computer Corporation, Bourne, Massachusetts, USA) buried $10 \mathrm{~cm}$ belowground, leaving thermocouple leads at ground level at the base of each plant, set to $2 \mathrm{sec}$ logging intervals. After the fire, we retrieved the dataloggers and scored each plant for fire severity: unburned; scorched (leaves blackened but parts remaining); or consumed (all leaves consumed). With the raw data from each datalogger, we calculated the maximum temperature and maximum one-minute mean temperature. Residence time was calculated and analyzed by totaling the time above $60{ }^{\circ} \mathrm{C}$, but was reported as the number of minutes. Our transects were affected mainly by headfires ignited using drip torches.

\section{Data analysis}

For fire effects, we excluded unburned plants but grouped scorched and consumed plants $(n=539)$. With a limited number of $\mathrm{HOBO}$ dataloggers available per fire, not all plants had fire data $(n=68)$. We also excluded data from damaged dataloggers $(n=27)$, mismatched times $(n=4)$, and unreasonable temperatures $\left(>1000{ }^{\circ} \mathrm{C} ; n=1\right)$. Dataloggers in six cases never exceeded the $60{ }^{\circ} \mathrm{C}$ minimum temperature to calculate residence time and were excluded as the plants for which the temperatures were recorded were not top killed. One-year post-fire survival data was never collected for some individuals $(n=88)$, and herbaceous plants $(n=7)$ and vines $(n=16)$ were excluded due to low replication. Our final dataset analyzed the one-year post-fire responses of 322 plants.

Maximum temperatures were highly correlated with one-minute mean temperatures $\left(r^{2}=0.829\right)$ but not residence times $\left(r^{2}=0.110\right)$; therefore, we excluded oneminute mean temperatures from analyses. Raw maximum temperature had the best distributed residuals and was used in analyses. Residence time was log transformed to meet normality assumptions.

We focused on the responses of survival and resprouting vigor in relation to maximum temperature, residence time (log transformed), species group, habitat, and burn season. Plant measurements taken within transects were not independent, so transect was evaluated as a random effect in all models. Survival analyses focused on postfire survival to one year $(n=322)$ using a generalized linear mixed model fit by maximum likelihood. Interaction effects were excluded from survival models due to low replication among combinations, which can produce unreliable outputs (Harrison et al. 2018). Resprouting vigor, based on relative growth rates (RGR) for height was calculated as the natural log of standing height at one year post fire minus the natural $\log$ of standing height pre fire $(n=287)$. Resprouting vigor was analyzed with a linear mixed model fit by reduced maximum likelihood including two-way interactions of species group with both habitat and season. Survival and RGR models were performed in $\mathrm{R}$ version 3.6 .2 with the packages lme 4 (Bates et al. 2015), lmerTest (Kuznetsova et al. 2017), and r $2 \mathrm{glmm}$ (Jaeger 2017). Fire characteristic analyses were performed in SPSS version 22 (IBM Corporation, Armonk, New York, USA).

Species were grouped into oaks, palmettos, ericaceous shrubs, other shrubs, and graminoids (Additional file 1). Habitats were Florida scrub (dominated by sand pines, Pinus clausa [Chapm. ex Engelm.]Vasey ex Sarg., and oaks), scrubby flatwoods, sandhill, and flatwoods. After each burn, the burn season was parametrized following the general definitions used by Platt et al. (2015), with wet season defined as July through October, dry season 
November through April, and fire season May through June. No fires occurred in April.

\section{Results}

\section{Fire characteristics}

We carried out 13 fires between 2006 and 2010 across four habitat types. Fires affected 539 tagged plants including 46 common resprouting species (Additional file 1). Fire completeness varied by fire. Within a transect, 17 to $100 \%$ of plants were affected by fire. Across all transects, $76 \%$ of plants were affected by fire; of these, $81 \%$ were consumed and $19 \%$ were scorched. Fires varied in size, time since previous fire, and in weather conditions during the burn (Table 2).

Fires had variable intensities. Based on 439 burned locations where dataloggers were deployed, maximum temperature ranged between 47 and $890{ }^{\circ} \mathrm{C}$, with a mean of $549{ }^{\circ} \mathrm{C}$ and a median temperature of $609{ }^{\circ} \mathrm{C}$. Residence times ranged from 0 to $83 \mathrm{~min}$, with mean and median residence times of 10 and $7 \mathrm{~min}$, respectively. Higher temperatures were correlated with a higher percentage of plants burned per transect (Pearson's $\mathrm{r}=$ $0.850, P<0.001)$. Consumed plants, relative to scorched plants, experienced higher maximum temperatures (mean $585^{\circ} \mathrm{C}$ versus $409^{\circ} \mathrm{C} ; \mathrm{P}<0.001$ in Mann Whitney $\mathrm{U}$ test; Field 2009) and longer residence times (mean 11 min versus 6 min; $P<0.001$ in Mann Whitney $U$ test).

Drought (KBDI) was positively correlated with residence time (Pearson's $\mathrm{r}=0.539, P=0.047$ ) but not with maximum temperature (Pearson's $r=0.059, P=0.841$ ). These results were consistent with intensity by burn season in that the generally droughty fire season (April to June) had similar maximum temperatures $(P=0.103)$, but twice the residence time of other seasons $(P=0.003$; Fig. 1A). Significantly longer residence times occurred during the fire season $(P<0.05$ for Tukey's post-hoc test; Field 2009) compared to both the wet season and dry season. A similar trend was observed across habitats, for which maximum temperatures did not vary $(P=0.579)$, but residence times were significantly different $(P<0.001$; Fig. 1B).

\section{Resprouting and survival}

Across all species affected by fire, $86 \%$ of plants resprouted post fire. First-year survival of resprouting plants was $91 \%$. After the first year post fire, cumulative survival averaged 92\% (up to 6 yr). First-year survival did not differ among scorched plants $(74 \%)$ relative to consumed plants $\left(73 \% ; X^{2}=0.162, P=0.688\right)$. Plants survived a wide range of maximum temperatures and residence times (Fig. 2).

Neither fire variable nor species group significantly influenced survival (Table 3). There was slightly lower survival in sand pine-oak scrub (83\%) compared to scrubby flatwoods (94\%), but this difference was only marginally significant.

\section{Growth of resprouting plants}

Recovery of height occurred rapidly in resprouting plants (Fig. 3), with most recovering to pre-fire heights four years post fire. RGR showed that the most rapid growth occurred within the first year. Across species, plants achieved $43,57,69$, and $82 \%$ of pre-fire height after six months, $1 \mathrm{yr}, 2 \mathrm{yr}$, and $3 \mathrm{yr}$ post fire, respectively.

Table 2 Data on the 13 prescribed fires, from 2006 to 2010, at Archbold Biological Station, Venus, Florida, USA, where the effect of prescribed fire on resprouting Florida vegetation was examined. Weather data were collected adjacent to fire. These include minimum relative humidity (Min $\mathrm{RH} ; \%)$ and wind speed $\left(\mathrm{km} \mathrm{h}^{-1}\right)$. Dominant vegetation included scrubby flatwoods, flatwoods, sandhill, and sand pine scrub

\begin{tabular}{|c|c|c|c|c|c|c|}
\hline Date & Burn season & Size (ha) & Year last burned & Min RH (\%) & Wind $\left(\mathrm{km} \mathrm{h}^{-1}\right)$ & Main vegetation \\
\hline 15 Mar 2006 & Dry & 15 & 1984 & 36 & 18 to 21 & Scrubby flatwoods \\
\hline 4 Aug 2006 & Wet & 8 & 2003 & 40 & 0 to 8 & Flatwoods \\
\hline 14 Jun 2007 & Fire & 55 & 2000 & 39 & 0 to 8 & Scrubby flatwoods \\
\hline 17 Jul 2007 & Wet & 50 & 1995 & 45 & 5 to 10 & Flatwoods \\
\hline 20 Jul 2007 & Wet & 28 & 1994 & 43 & 5 to 6 & Sandhill \\
\hline 9 Aug 2007 & Wet & 18 & 1992 & 45 & 5 to 10 & Scrubby flatwoods \\
\hline 9 Aug 2007 & Wet & 18 & 1991 & 45 & 5 to 10 & Scrubby flatwoods \\
\hline 16 Aug 2007 & Wet & 11 & 1993 & 41 & 8 & Sand pine scrub \\
\hline 14 Aug 2008 & Wet & 56 & 2003 & 60 & 13 to 19 & Flatwoods \\
\hline 18 Aug 2009 & Wet & 8 & 1996 & 57 & 3 to 10 & Sandhill \\
\hline 25 Sep 2009 & Wet & 12 & 1992 & 48 & 5 to 11 & Scrubby flatwoods \\
\hline 11 Jun 2010 & Fire & 53 & 1990 & 43 & 6 to 13 & Sandhill \\
\hline 29 Jun 2010 & Fire & 24 & 2004 & 55 & 6 to 13 & Sandhill \\
\hline
\end{tabular}



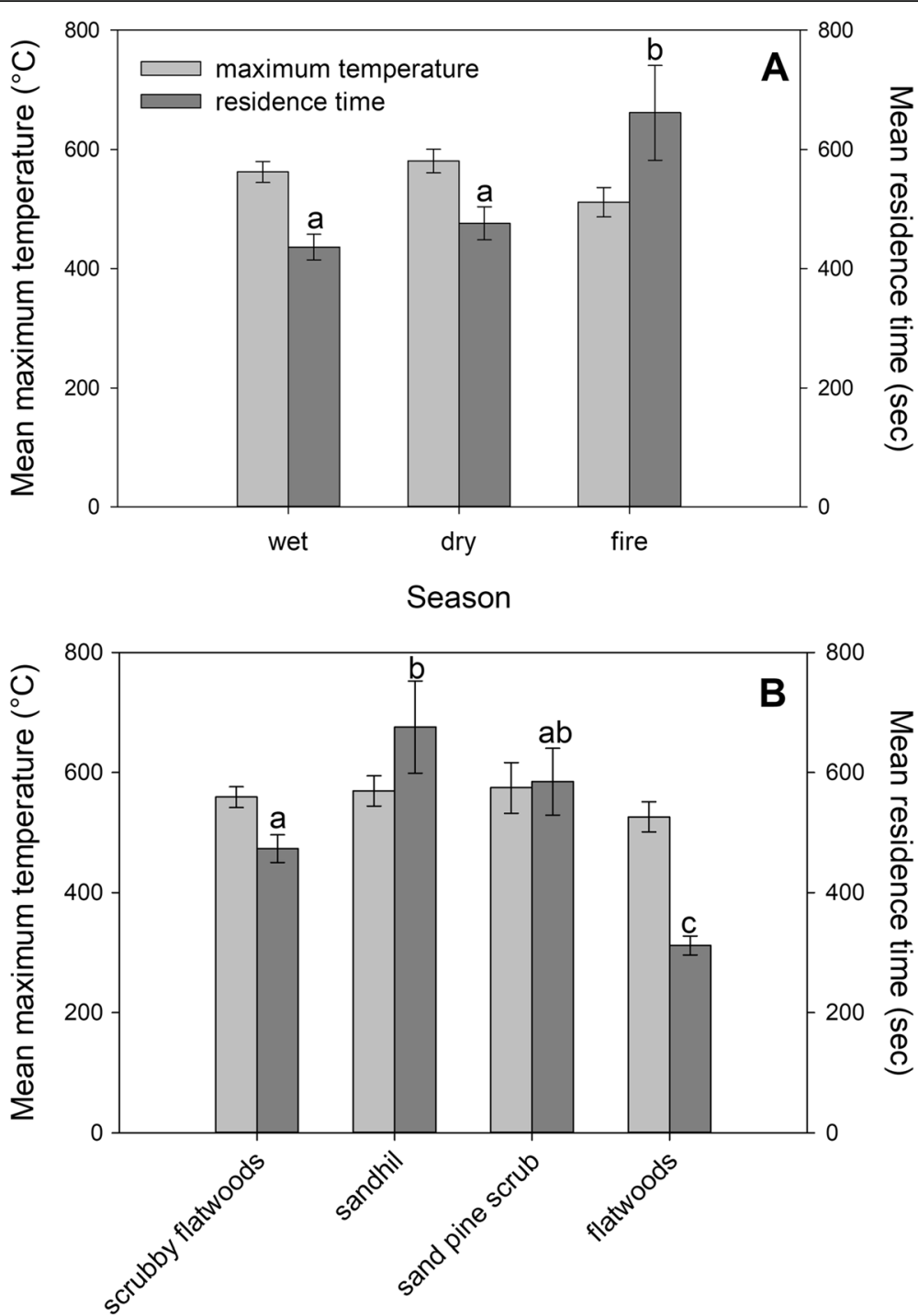

\section{Habitat}

Fig. 1 Fire intensity variation following 13 prescribed fires from 2006 to 2010 at Archbold Biological Station, Venus, Florida, USA, where the effect of prescribed fire on resprouting Florida vegetation was examined. Fire intensities were calculated as the mean maximum temperatures $\left({ }^{\circ} \mathrm{C}\right)$ and mean residence time in seconds for temperatures that exceeded $60^{\circ} \mathrm{C}$. Error bars are one standard error of the mean. Fire intensities were examined across (A) three seasons and (B) four habitats. Significant differences $(P<0.05$ Tukey's post-hoc test) in fire variables among season or habitats are indicated with differing lower case letters

Maximum temperature, residence time, burn season, habitat, and species group did not significantly affect postfire RGR. One-year post-fire RGR was significantly affected by the interaction of burn season and species group (Table 4). Specifically, ericaceous species were the slowest to recover following fires in the wet season (Fig. 4). Oaks, ericads, and shrubs all had slow recovery, with shrubs recovering slightly faster after being burned in the dry season. Palms recovered quickly, regardless of burn season. Graminoid recovery varied by burn season, with one-year post-fire heights exceeding pre-fire heights when burned in the dry and wet seasons.

\section{Discussion}

Resprouting perennial plants that dominate Florida scrub, flatwoods, and many other vegetation types in Florida (Menges and Kohfeldt 1995; Weekley and Menges 2003) appear resilient to fire intensities found in this study, as measured by maximum temperatures and residence times. Fire seasons also had little effect on resprouting. Resprouting percentages and first-year survival were high ( $>80 \%$ for all groups), even for this study that included many very small plants (pre-fire height range from 1 to $610 \mathrm{~cm}$ ). In addition, temperature and fire season had little effect on survival or growth over 

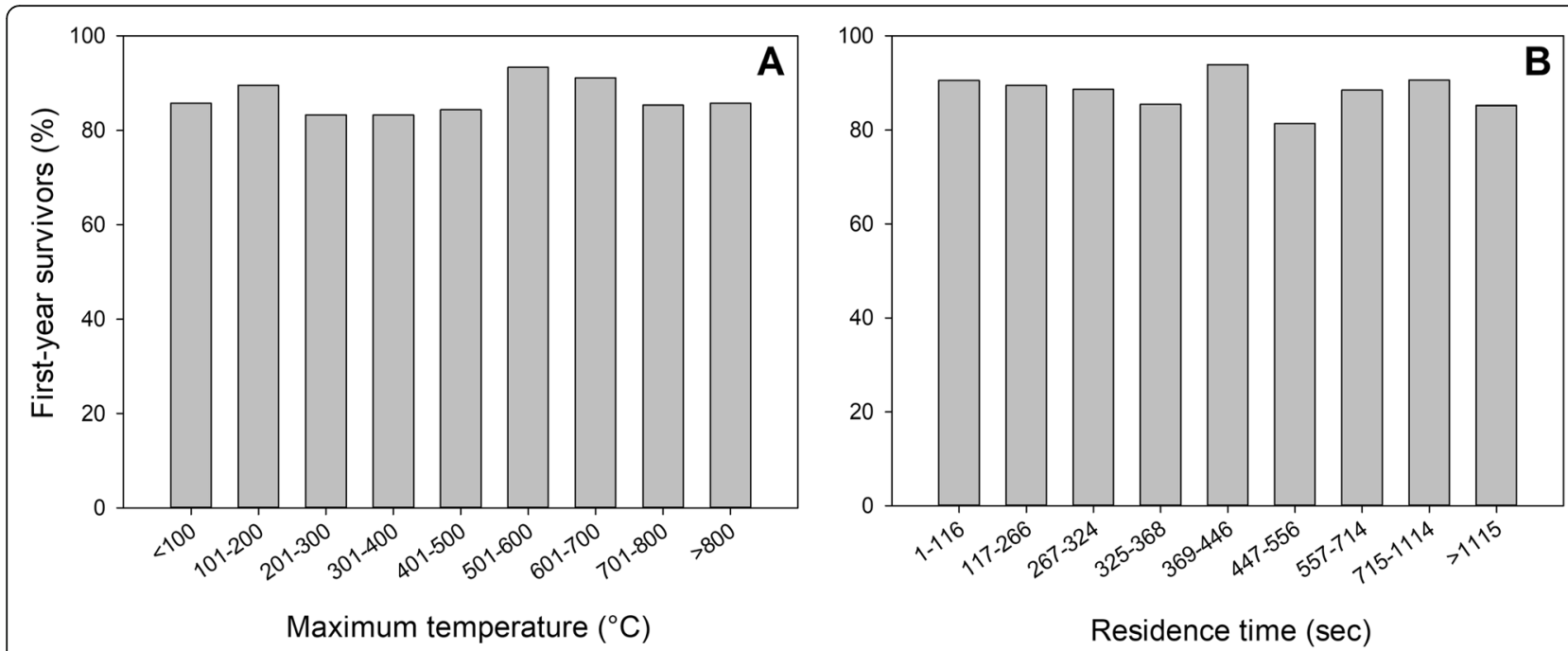

Fig. 2 First-year survival of plants (\%) following one of 13 prescribed fires from 2006 to 2010 at Archbold Biological Station, Venus, Florida, USA, where the effect of prescribed fire on resprouting Florida vegetation was examined. Dataloggers buried at the base of each plant recorded a range of $(\mathbf{A})$ maximum temperatures in $100{ }^{\circ} \mathrm{C}$ bins and $(\mathbf{B})$ residence times in seconds above $60{ }^{\circ} \mathrm{C}$ in nine bins

the first year. In this study, most of the burns were accomplished in the wet season, so our ability to detect fire season effects was limited. Similar results have been found for resprouting shrubs in longleaf pine (Pinus palustris Mill.) savannas (Drewa et al. 2002), but fire temperatures and residence times sometimes affected post-fire survival and growth in other habitats (e.g., Lloret and López-Soria 1993; Wright and Clarke 2007; Fernández et al. 2013), perhaps because of differences in fire intensities or post-fire resprouting adaptations.

Post-fire growth was rapid, as is typical of plants in Florida ecosystems (Abrahamson 1984; Schmalzer 2003;

Table 3 Generalized linear mixed model predicting first-year survival of resprouting plants $(n=322)$ following 13 prescribed fires, from 2006 to 2010, at Archbold Biological Station, Venus, Florida, USA, where the effect of prescribed fire on resprouting Florida vegetation was examined. Plants within transects were not independent so transect was evaluated as a random effect (variance $<0.001)$ in the model. Variables included maximum fire temperature, residence time in seconds (log), burn season, habitat, and species groups. Reference categories for burn season were "Fire," "Scrubby Flatwoods" for habitat, and "Oaks" for species groups. For each variable, the estimated coefficient ( $\beta \pm$ standard error [SE]) shows the relationship and magnitude of change with the probability of survival. Sample size $(n)$ and mean first-year survival is provided for each group. Marginal predictors are in italics $(P<0.1)$. The random effects of transect were also highly significant $(P<0.001)$

\begin{tabular}{|c|c|c|c|c|c|c|}
\hline \multicolumn{2}{|l|}{ Fixed effects } & $\beta$ (SE) & $P$-value & $R^{2}$ & $n$ & First-year survival (\%) \\
\hline \multicolumn{2}{|l|}{ Intercept } & $2.92(1.848)$ & 0.114 & 0.039 & & 91.0 \\
\hline \multicolumn{2}{|c|}{ Maximum temperature } & $<0.01(0.001)$ & 0.757 & $<0.001$ & 322 & \\
\hline \multicolumn{2}{|c|}{ Residence time (log) } & $-0.26(0.744)$ & 0.727 & 0.001 & 322 & \\
\hline \multirow[t]{3}{*}{ Burn season } & Fire & & & & 167 & 89.2 \\
\hline & Wet & $0.63(0.634)$ & 0.323 & $<0.001$ & 85 & 94.1 \\
\hline & Dry & $0.93(0.736)$ & 0.204 & 0.001 & 70 & 91.4 \\
\hline \multirow[t]{4}{*}{ Habitat } & Scrubby flatwoods & & & & 143 & 93.7 \\
\hline & Sandhill & $0.39(0.678)$ & 0.565 & $<0.001$ & 72 & 94.4 \\
\hline & Sand pine-oak scrub & $-1.13(0.673)$ & 0.094 & 0.004 & 36 & 83.3 \\
\hline & Flatwoods & $-0.84(0.559)$ & 0.131 & 0.004 & 71 & 85.9 \\
\hline \multirow[t]{5}{*}{ Species group } & Oaks & & & & 97 & 93.8 \\
\hline & Palms & $1.11(1.101)$ & 0.313 & 0.007 & 48 & 97.9 \\
\hline & Ericads & $-0.32(0.653)$ & 0.620 & 0.001 & 70 & 91.4 \\
\hline & Graminoids & $-0.65(0.723)$ & 0.368 & 0.002 & 32 & 87.5 \\
\hline & Shrubs & $-0.92(0.564)$ & 0.101 & 0.008 & 75 & 84.0 \\
\hline
\end{tabular}




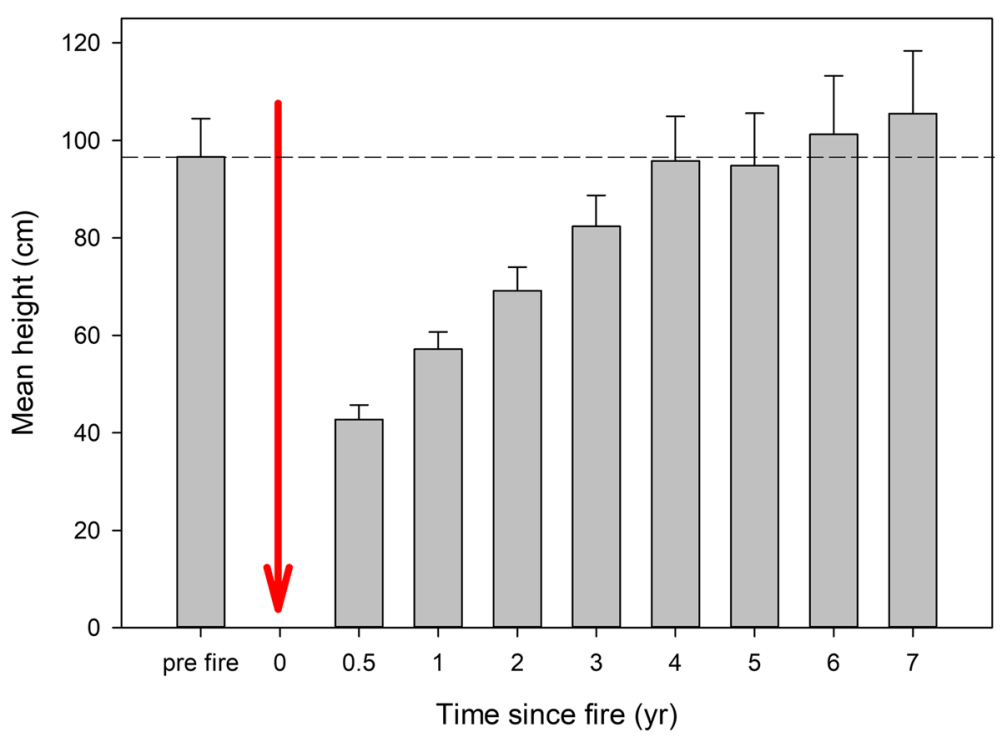

Fig. 3 Recovery based on mean height ( $\pm 95 \%$ confidence interval) across 46 plant species native to Florida vegetation. Plants were affected by one of 13 prescribed fires, between 2006 to 2010, at Archbold Biological Station, Venus, Florida, USA, while examining the effect of prescribed fire on resprouting. Height was recorded pre fire, assessed the day of the fire (red arrow), post fire at six months (0.5), one year, and then yearly up to seven years. Red arrow indicates fire that top-killed resprouting plants

Maguire and Menges 2011). Although not statistically different from other groups, post-fire growth was relatively rapid for graminoids and palmettos. Rapid recovery of palmettos has been shown in other studies (Schmalzer and Hinkle 1992; Schmalzer 2003; Menges et al. 2020). The particularly fast recovery of palmettos (Abrahamson and Abrahamson 2006; Menges et al. 2020), relative to competitors like oaks, is a widely observed phenomenon that can be seen in photos and time-lapse videos of vegetation recovery. Slower recovery of oaks, ericads, and other shrubs allows temporary gaps to form, which are important to subordinate species, including herbs, in vegetation types such as scrubby flatwoods (Dee and Menges 2014). Vegetation types that have a higher proportion of obligate seeding species have larger and more persistent gaps (Menges et al. 2017b), important for the viability of many of these species (Quintana-Ascencio et al. 2003; Menges and QuintanaAscencio 2004).

Prior time-since-fire did not vary widely in this study and, in preliminary analyses, was not an important predictor of post-fire responses. For some sandhill sites and one scrubby flatwoods site, time-since-fire was greater than the presumed historical fire-return interval. The fact that resprouting responses were robust even in these relatively long-unburned sites emphasizes the resilience of these resprouting species to a range of burn timings.

Differences in recovery rates by species group were not significant in this study. Other studies have found differences in species group responses to fire (Schmalzer 2003; Menges et al. 2020) that could have long-term effects on community structure. Frequent fires, by favoring rapidly recovering palmettos (Menges et al. 2020), could gradually increase their dominance. Palmettos have extremely high belowground:aboveground ratios (Saha et al. 2010), low mortality, high post-fire flowering (Abrahamson 1999), and slow growth (Abrahamson and Abrahamson 2009), which allows them to persist as dominants for many decades. However, palmettos remain in the shrub layer while oaks and other shrubs can form a low tree canopy given long fire-free intervals (Myers 1985; Menges et al. 1993). Oaks tend to increase, and palmettos decrease, in long-unburned scrub and sandhill sites (Menges et al. 1993).

Fire is critical for maintaining the structure of Florida scrub and other vegetation types, which is key for species adapted for post-fire conditions. These include the Florida scrub-jay (Aphelocoma coerulescens Bosc), which prefers lower shrub heights and bare sand patches to bury acorns (Breininger and Schmalzer 1990). Gopher tortoises (Gopherus polyphemus Daudin), which are most abundant in xeric upland habitats, prefer areas with abundant forbs and graminoid plants (Mushinsky et al. 2006), which can be outcompeted by shrubs if areas burn infrequently or patchily (Provencher et al. 2001; Reinhart and Menges 2004). Many narrow endemic herbs and subshrubs require gaps among dominant shrubs (Quintana-Ascencio et al. 2003; Menges and Quintana-Ascencio 2004), which are expanded with fire (Menges et al. 2017b).

While fire plays a key role, it does not appear that variations in fire intensity (this paper) and fire frequency 
Table 4 Linear mixed effects model predicting change in relative growth rates (RGR) from pre-fire heights to one-year post-fire heights ( $n=287$ ) following 13 prescribed fires, from 2006 to 2010, at Archbold Biological Station, Venus, Florida, USA, where the effect of prescribed fire on resprouting Florida vegetation was examined. Plants within transects were not independent so transect was evaluated as a random effect (variance $=0.011$ ) in the model. Variables included maximum fire temperature, residence time in seconds (log), burn season, habitat, species group, and two-way interactions. Reference categories for burn season were "Fire", "Scrubby Flatwoods" for habitat, and "Oaks" for species groups. The burn season * habitat interaction was not included due to low or missing cells. For each variable, the estimated coefficient ( $\beta \pm$ standard error [SE]) shows the relationship and magnitude of change with relative growth. Sample size $(n)$ is provided for each group and the mean first-year relative growth rate (RGR). Significant effects $(P<0.05)$ are highlighted in bold and marginal predictors are in italics $(P<0.1)$. The random effects of transect were also not significant $(P<0.001)$

\begin{tabular}{|c|c|c|c|c|c|c|}
\hline \multicolumn{2}{|l|}{ Fixed effects } & $\beta$ (SE) & $P$-value & $\mathrm{R}^{2}$ & $n$ & First year RGR \\
\hline \multicolumn{2}{|l|}{ Intercept } & $-0.70(0.370)$ & 0.062 & 0.254 & & -0.410 \\
\hline \multicolumn{2}{|c|}{ Maximum temperature } & $<0.01(<0.001)$ & 0.107 & 0.009 & 287 & \\
\hline \multicolumn{2}{|c|}{ Residence time (log) } & $0.11(0.128)$ & 0.401 & 0.003 & 287 & \\
\hline \multirow[t]{3}{*}{ Burn season } & Fire & & & & 148 & -0.457 \\
\hline & Wet & $0.32(0.211)$ & 0.146 & 0.010 & 78 & -0.291 \\
\hline & Dry & $0.14(0.241)$ & 0.557 & 0.002 & 61 & -0.516 \\
\hline \multirow[t]{4}{*}{ Habitat } & Scrubby flatwoods & & & & 130 & -0.372 \\
\hline & Sandhill & $-0.15(0.209)$ & 0.486 & 0.002 & 68 & -0.527 \\
\hline & Sand pine-oak scrub & $-0.43(0.244)$ & 0.105 & 0.014 & 30 & -0.384 \\
\hline & Flatwoods & $-0.37(0.244)$ & 0.130 & 0.009 & 59 & -0.441 \\
\hline \multirow[t]{5}{*}{ Species groups } & Oaks & & & & 90 & -0.535 \\
\hline & Palms & $0.43(0.291)$ & 0.140 & 0.007 & 47 & -0.113 \\
\hline & Ericads & $0.25(0.245)$ & 0.316 & 0.004 & 61 & -0.654 \\
\hline & Graminoids & $0.46(0.625)$ & 0.463 & 0.002 & 27 & 0.250 \\
\hline & Shrubs & $-0.25(0.305)$ & 0.415 & 0.002 & 62 & -0.567 \\
\hline \multicolumn{2}{|l|}{ Sandhill*Palms } & $0.21(0.310)$ & 0.509 & 0.001 & & \\
\hline \multicolumn{2}{|c|}{ Sand pine-oak scrub*Palms } & $0.50(0.397)$ & 0.205 & 0.005 & & \\
\hline \multicolumn{2}{|l|}{ Flatwoods*Palms } & $0.33(0.353)$ & 0.370 & 0.003 & & \\
\hline \multicolumn{2}{|l|}{ Sandhill*Ericads } & $-0.17(0.328)$ & 0.596 & 0.001 & & \\
\hline \multicolumn{2}{|c|}{ Sand pine-oak scrub*Ericads } & $0.81(0.498)$ & 0.103 & 0.009 & & \\
\hline \multicolumn{2}{|c|}{ Flatwoods*Ericads } & $0.42(0.302)$ & 0.166 & 0.007 & & \\
\hline \multicolumn{2}{|c|}{ Sandhill*Graminoids } & $-0.78(0.502)$ & 0.122 & 0.008 & & \\
\hline \multicolumn{2}{|c|}{ Sand pine-oak scrub*Graminoids } & $-0.16(0.526)$ & 0.760 & $<0.001$ & & \\
\hline \multicolumn{2}{|c|}{ Flatwoods*Graminoids } & $-0.34(0.445)$ & 0.445 & 0.002 & & \\
\hline \multicolumn{2}{|l|}{ Sandhill*Shrubs } & $0.06(0.293)$ & 0.839 & $<0.001$ & & \\
\hline \multicolumn{2}{|c|}{ Sand pine-oak scrub*Shrubs } & $0.27(0.427)$ & 0.524 & 0.001 & & \\
\hline \multicolumn{2}{|c|}{ Flatwoods*Shrubs } & $0.41(0.297)$ & 0.166 & 0.007 & & \\
\hline \multicolumn{2}{|l|}{ Wet*Palms } & $-0.33(0.309)$ & 0.284 & 0.004 & & \\
\hline \multicolumn{2}{|l|}{ Dry*Palms } & $-0.03(0.340)$ & 0.952 & $<0.001$ & & \\
\hline \multicolumn{2}{|l|}{ Wet ${ }^{*}$ Ericads } & $-0.84(0.292)$ & 0.004 & 0.029 & & \\
\hline \multicolumn{2}{|l|}{ Dry*Ericads } & $-0.29(0.314)$ & 0.355 & 0.003 & & \\
\hline \multicolumn{2}{|l|}{ Wet*Graminoids } & $0.72(0.752)$ & 0.342 & 0.003 & & \\
\hline \multicolumn{2}{|l|}{ Dry*Graminoids } & $0.97(0.708)$ & 0.173 & 0.006 & & \\
\hline \multicolumn{2}{|l|}{ Wet*Shrubs } & $-0.01(0.303)$ & 0.965 & $<0.001$ & & \\
\hline \multicolumn{2}{|l|}{ Dry*Shrubs } & 0.35 (0.376) & 0.357 & 0.003 & & \\
\hline
\end{tabular}




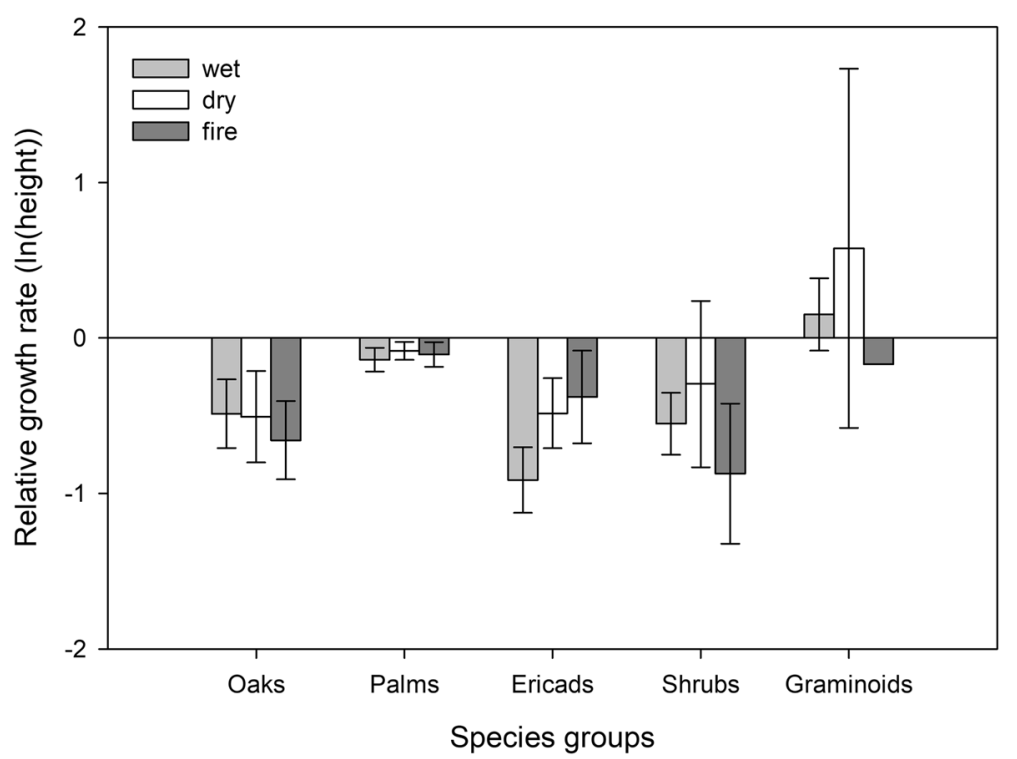

Fig. 4 Relative growth rates ( $\pm 95 \%$ confidence interval) of resprouting plants based on the change in height from pre fire to one year post fire across all species groups $(n=287)$, from data collected during examination of the effect of prescribed fire on Florida vegetation. Thirteen prescribed fires at Archbold Biological Station, from 2006 to 2010, occurred either during the wet (late June to October), dry (November to early April), or fire (late April to late June) season. A linear mixed effect model indicated that there was a significant interaction between burning in the wet season and ericads $(P=0.008)$

(Menges et al. 2020) are especially important in affecting resprouting shrub dominance. Rather, differences in species life histories in relation to burn season (Menges 2007), and the patchy nature of fires in Florida scrub (Menges et al. 2017a), combine to create higher diversity over time and across space. Burn season can affect flowering and seed production of many species (e.g., Platt et al. 1988; Mulligan and Kirkman 2002), which could affect subsequent recruitment (Knox and Clarke 2006). Patchy fires that allow for unburned refugia are important for fire-sensitive, non-seed-banking plants, and can therefore increase landscape level diversity (Russell-Smith et al. 2002).

\section{Conclusions and Management Recommendations}

This research shows that fire temperatures and residence times typical of prescribed burns in Florida scrub and related vegetation do not appear to have major impacts on resprouting response. Wildfires, because they often burn under more extreme conditions and into long-unburned vegetation, could have higher temperatures or residence times (data are lacking on fire intensities in Florida wildfires). Resprouters in Florida scrub are also resilient to a range of fire frequencies, including annual fires, for up to six years (Menges et al. 2020). Climate change is likely to affect fire regimes (Young et al. 2017), with the southeastern US predicted to have warmer, drier, and more variable precipitation, which may result in longer lightning-ignited fire seasons and increased fire frequencies, intensities, and areas burned (Bedel et al. 2013; Mitchell et al. 2014; Prestemon et al. 2016; Fill et al.
2019). Changes in climate or in fire regime due to climate change could affect resprouting responses, although there is little research on this topic. Absent these fundamental shifts in resprouting responses, changes in the prescribed fire regime are unlikely to cause major shifts in the dominant, long-lived resprouting shrubs that dominate many Florida ecosystems.

\section{Supplementary Information}

The online version contains supplementary material available at https://doi. org/10.1186/s42408-021-00101-8.

Additional file 1. Resprouting species, their assigned species group, and number of cases included in the dataset (total 539) from our study of Florida vegetation habitat following 13 prescribed fires, from 2006 to 2010, at Archbold Biological Station, Venus, Florida, USA. Nomenclature is based on the Atlas of Florida Plants https://florida.plantatlas.usf.edu/ (accessed 24 August 2020).

\section{Acknowledgements}

Thanks to M. Rickey and W. Abrahamson for useful discussions of fire ecology. Thanks also to B. Poirier, S. McAlister, and S. Haller Crate and the many dozens of research interns that helped collect these data. We appreciate the efforts of K. Main and other Archbold staff who conducted the prescribed burns.

\section{Authors' contributions}

ESM conceived of the study. ESM, SAS, and GC helped design the study and collect data. ESM, SAS, and SMK analyzed the data. EM, SAS, and SMK wrote the manuscript. All authors edited and approved the final manuscript.

\section{Funding}

Funding from the National Science Foundation DEB0812717 was greatly appreciated. 


\section{Availability of data and materials}

Data are posted online at EDI Data Portal: https://10.6073/pasta/de88483cb6 767157e3d430ba8dcb39cd

\section{Declarations}

\section{Ethics approval and consent to participate}

Not applicable.

\section{Consent for publication}

Not applicable.

\section{Competing interests}

The authors declare that they have no competing interests.

\section{Author details}

'Plant Ecology Program, Archbold Biological Station, 123 Main Drive, Venus, Florida 33960, USA. ${ }^{2}$ Agronomy Department, University of Florida, 1678 McCarty Drive, 3105 McCarty Hall B, Gainesville, Florida 32611, USA.

Received: 21 September 2020 Accepted: 3 April 2021

Published online: 20 May 2021

\section{References}

Abrahamson, W.G. 1984. Post-fire recovery of Florida Lake Wales Ridge vegetation. American Journal of Botany 71 (1): 9-21. https://doi.org/10.1002/ j.1537-2197.1984.tb12479.x.

Abrahamson, W.G. 1999. Episodic reproduction in two fire-prone palms, Serenoa repens and Sabal etonia (Palmae). Ecology 80 (1): 100-115. https://doi.org/1 0.1890/0012-9658(1999)080[0100:ERITFP]2.0.CO;2.

Abrahamson, W.G., and C.R. Abrahamson. 2006. Post-fire canopy recovery in two fire-adapted palms, Serenoa repens and Sabal etonia (Arecaceae). Florida Scientist 69: 69-79.

Abrahamson, W.G., and C.R. Abrahamson. 2009. Life in the slow lane: palmetto seedlings exhibit remarkable survival but slow growth in Florida's nutrientpoor uplands. Castanea 74 (2): 123-132. https://doi.org/10.2179/08-033.1.

Abrahamson, W.G., A.F. Johnson, J.N. Layne, and P.A. Peroni. 1984. Vegetation of the Archbold Biological Station, Florida: an example of the southern Lake Wales Ridge. Florida Scientist 47: 209-251.

Archibald, S. 2016. Managing the human component of fire regimes: lessons from Africa. Philosophical Transactions of the Royal Society B 371 (1696): 20150346. https://doi.org/10.1098/rstb.2015.0346.

Bates, D., M. Maechler, B. Bolker, and S. Walker. 2015. Fitting linear mixed-effects models Using Ime4. Journal of Statistical Software 67 (1): 1-48. https://doi. org/10.18637/jss.V067.01.

Bedel, A.P., T.L. Mote, and S.L. Goodrick. 2013. Climate change and associated fire potential for the south-eastern United States in the 21st century. International Journal of Wildland Fire 22 (8): 1034-1043. https://doi.org/10.1 071 WF13018.

Bellingham, P.J., and A.D. Sparrow. 2000. Resprouting as a life history strategy in woody plant communities. Oikos 89 (2): 409-416. https://doi.org/10.1034/j.1 600-0706.2000.890224.x.

Bond, W.J., and J.E. Keeley. 2005. Fire as a global 'herbivore': the ecology and evolution of flammable ecosystems. Trends in Ecology \& Evolution 20 (7): $387-$ 394. https://doi.org/10.1016/j.tree.2005.04.025.

Bond, W.J., and J.J. Midgley. 2001. Ecology of sprouting in woody plants: the persistence niche. Trends in Ecology \& Evolution 16 (1): 45-51. https://doi. org/10.1016/S0169-5347(00)02033-4.

Breininger, D.R., and P.A. Schmalzer. 1990. Effects of fire and disturbance on plants and birds in a Florida oak/palmetto scrub community. American Midland Naturalist 123 (1): 64-74. https://doi.org/10.2307/2425760.

Clarke, P.J., D.M. Bell, and M.J. Lawes. 2015. Testing the shifting persistence niche concept: plant resprouting along gradients of disturbance. American Naturalist 185 (6): 747-755. https://doi.org/10.1086/681160.

Clarke, P.J., K.J.E. Knox, K.E. Wills, and M. Campbell. 2005. Landscape patterns of woody plant response to crown fire: disturbance and productivity influence sprouting ability. Journal of Ecology 93 (3): 544-555. https://doi.org/10.1111/ j.1365-2745.2005.00971.x.

Dee, J.R., and E.S. Menges. 2014. Gap ecology in Florida scrubby flatwoods: Effects of time-since-fire, gap size, gap aggregation, and microhabitat on species occurrence and composition. Journal of Vegetation Science 25 (5): 1235-1246. https://doi.org/10.1111/jvs.12170.

Drewa, P.B., W.J. Platt, and E.B. Moser. 2002. Fire effects on resprouting of shrubs in headwaters of southeastern longleaf pine savannas. Ecology 83 (3): $755-$ 767. https://doi.org/10.1890/0012-9658(2002)083[0755:FEOROS]2.0.CO;2.

Duncan, B.W., F.W. Adrian, and E.D. Stolen. 2010. Isolating the lightning ignition regime from a contemporary background fire regime in east-central Florida, USA. Canadian Journal of Forest Research 40 (2): 286-297. https://doi.org/1 0.1139/X09-193.

Ehrlen, J., and W.F. Morris. 2015. Predicting changes in the distribution and abundance of species under environmental change. Ecology Letters 18 (3): 303-314. https://doi.org/10.1111/ele.12410.

Estill, J., and M.B. Cruzan. 2001. Phytogeography of rare plant species endemic to the Southeastern United States. Castanea 66: 3-23.

Fernández, C., J.A. Vega, and T. Fonturbel. 2013. Does fire severity influence shrub resprouting after spring prescribed burning? Acta Oecologica 48: 30-36. https://doi.org/10.1016/j.actao.2013.01.012.

Field, A. 2009. Discovering statistics using SPSS. 3rd ed. Los Angeles: Sage.

Fill, J.M., C.N. Davis, and R.M. Crandall. 2019. Climate change lengthens southeastern USA lightning-ignited fire seasons. Global Change Biology 25: 3562-3569. https://doi.org/10.1111/gcb.14727.

Guyette, R.P., and D.C. Dey 2000. Humans, topography, and wildland fire: the ingredients for long-term patterns in ecosystems. In Proceedings of the workshop on fire, people, and the central hardwoods landscape, compiled by D.A. Yaussy, Pages 28-36. USDA Forest Service General Technical Report NE274: Upper Darby: USDA Forest Service, Northeastern Research Station.28-36

Guyette, R.P., M.C. Stambaugh, D.C. Dey, and R.M. Muzika. 2012. Predicting fire frequency with chemistry and climate. Ecosystems 15 (2): 322-335. https:// doi.org/10.1007/s10021-011-9512-0.

Harrison, X.A., L. Donaldson, M.E. Correa-Cano, J. Evans, D.N. Fisher, C.E.D. Goodwin, B.S. Robinson, D.J. Hodgson, and R. Inger. 2018. A brief introduction to mixed effects modelling and multi-model inference in ecology. PeerJ 6: 1-32. https://doi.org/10.7717/peerj.4794.

Hmielowski, T.L., K.M. Robertson, and W.J. Platt. 2014. Influence of season and method of top-kill on resprouting characteristics and biomass of Quercus nigra saplings from a southeastern U.S. pine-grassland ecosystem. Plant Ecology 215 (10): 1221-1231. https://doi.org/10.1007/s11258-014-0380-5.

Jaeger, B. 2017. r2glmm: Computes R squared for mixed (multilevel) models. R package version 0.1.2. https://CRAN.R-project.org/package $=r 2 \mathrm{glmm}$.

Johnson, A.F., and W.G. Abrahamson. 1990. A note on the fire responses of species in rosemary scrub on the southern Lake Wales Ridge. Florida Scientist 53: 138-143.

Keeley, J.E., W.J. Bond, R.A. Bradstock, J.G. Pausas, and P.W. Rundel. 2011a. Fire and the fire regime framework. In Fire in Mediterranean ecosystems: ecology, evolution and management, 30-57. Cambridge: Cambridge University Press. https://doi.org/10.1017/CBO9781139033091.003.

Keeley, J.E., J.G. Pausas, P.W. Rundel, W.J. Bond, and R.A. Bradstock. 2011b. Fire as an evolutionary pressure shaping plant traits. Trends in Plant Science 16 (8): 406-411. https://doi.org/10.1016/j.tplants.2011.04.002.

Keetch, J.J., and G. Byram. 1968. A drought index for forest fire control. In USDA Forest Service Research Paper SE-38. Asheville: USDA, Forest Service, Southeastern Forest Experiment Station.

Klimes, J., and L. Klimes. 2007. Bud banks and their role in vegetative regeneration - a literature review and proposal for simple classification and assessment. Perspectives in Plant Ecology, Evolution and Systematics 8 (3): 115 129. https://doi.org/10.1016/j.ppees.2006.10.002.

Knox, K.J.E., and P.J. Clarke. 2006. Fire season and intensity affect shrub recruitment in temperate sclerophyllous woodlands. Oecologia 149 (4): 730 739. https://doi.org/10.1007/s00442-006-0480-6.

Kuznetsova, A., P.B. Brockhoff, and R.H.B. Christensen. 2017. ImerTest package: tests in linear mixed effects models. Journal of Statistical Software 82 (13): 126. https://doi.org/10.18637/jss.v082.i13.

Lamont, B.B., and T. He. 2017. Fire-proneness as prerequisite for the evolution of fire-adapted traits. Trends in Plant Science 22 (4): 278-288. https://doi.org/10.1 016/j.tplants.2016.11.004.

Lloret, F., and L. López-Soria. 1993. Resprouting of Erica multiflora after experimental fire treatments. Journal of Vegetation Science 4 (3): 367-374. https://doi.org/10.2307/3235595.

Maguire, A.J., and E.S. Menges. 2011. Post-fire growth strategies of resprouting Florida scrub species. Fire Ecology 7 (3): 12-25. https://doi.org/10.4996/ fireecology. 0703012. 
Maliakal, S.K., E.S. Menges, and J.S. Denslow. 2000. Community composition and regeneration of Lake Wales Ridge wiregrass flatwoods in relation to timesince-fire. Journal of the Torrey Botanical Society 127 (2): 125-138. https://doi. org/10.2307/3088690.

Menges, E.S. 1999. Ecology and conservation of Florida scrub. In The savanna, barren, and rock outcrop communities of North America., edited by R.C. Anderson, J.S. Fralish, and J, Baskin, J. Pages 7-22. Cambridge: Cambridge University Press. doi: https://doi.org/10.1017/CBO9780511574627.002

Menges, E.S. 2007. Integrating demography and fire management: an example from Florida scrub. Australian Journal of Botany 55 (3): 261-272. https://doi. org/10.1071/BT06020.

Menges, E.S., W.G. Abrahamson, K.T. Givens, N.P. Gallo, and J.N. Layne. 1993. Twenty years of vegetation change in five unburned Florida plant communities. Journal of Vegetation Science 4 (3): 375-386. https://doi.org/1 $0.2307 / 3235596$.

Menges, E.S., S.J.H. Crate, and P.F. Quintana-Ascencio. 2017b. Dynamics of gaps, vegetation, and plant species with and without fire. American Journal of Botany 104 (12): 1825-1836. https://doi.org/10.3732/ajb.1700175.

Menges, E.S., and N.M. Kohfeldt. 1995. Life history strategies of Florida scrub plants in relation to fire. Bulletin of the Torrey Botanical Club 122 (4): 282-297. https://doi.org/10.2307/2996320.

Menges, E.S., K.N. Main, R.L. Pickert, and K. Ewing. 2017a. Evaluation of a fire management plan for fire regime goals in a Florida landscape. Natural Areas Journal 37 (2): 212-227. https://doi.org/10.3375/043.037.0210.

Menges, E.S., and P.F. Quintana-Ascencio. 2004. Population viability with fire in Eryngium cuneifolium: deciphering a decade of demographic data. Ecological Monographs 74 (1): 79-99. https://doi.org/10.1890/03-4029.

Menges, E.S., S.A. Smith, K. Main, J. Olano, J. Schafer, and G. Clarke. 2020. Effects of frequent fire and mowing on resprouting shrubs of Florida scrub. Fire Ecology 16 (1): 10. https://doi.org/10.1186/s42408-020-0069-1.

Mitchell, R.J., Y. Liu, J.J. O'Brien, K.J. Elliott, G. Starr, C.F. Miniat, and J.K. Hiers. 2014. Future climate and fire interactions in the southeastern region of the United States. Forest Ecology and Management 327: 316-326. https://doi.org/10.1016/ j.foreco.2013.12.003

Moreno, J.M., and W.C. Oechel. 1991. Fire intensity and herbivory effects on postfire resprouting of Adenostema fasciculatum in southern California chaparral. Oecologia 85 (3): 429-433. https://doi.org/10.1007/BF00320621.

Mulligan, M.K., and L.K. Kirkman. 2002. Burning influences on wiregrass (Aristida beyrichiana) restoration plantings: natural seedling recruitment and survival. Restoration Ecology 10 (2): 334-339. https://doi.org/10.1046/j.1526-100X.2002. 00041.x.

Mushinsky, H.R., E.D. McCoy, J.E. Berish, R.E. Ashton, and D.W. Wilson. 2006. Biology and Conservation of Florida Turtles. Chelonian Research Monographs 3: $350-375$

Myers, R.L. 1985. Fire and the dynamic relationship between Florida sandhill and sand pine scrub vegetation. Bulletin of the Torrey Botanical Club 112 (3): 241252. https://doi.org/10.2307/2996539.

Olano, J.M., E.S. Menges, and E. Martínez. 2005. Carbohydrate storage in five resprouting Florida scrub plants across a fire chronosequence. New Phytologist 170 (1): 99-106. https://doi.org/10.1111/j.1469-8137.2005.01634.x.

Ostertag, R., and E.S. Menges. 1994. Patterns of reproductive effort with time since last fire in Florida scrub plants. Journal of Vegetation Science 5 (3): $303-$ 310. https://doi.org/10.2307/3235853.

Pausas, J.G., B.B. Lamont, S. Paula, B. Appezzato-da-Gloria, and A. Fidelis. 2018. Unearthing belowground bud banks in fire-prone ecosystems. New Phytologist 217 (4): 1435-1448. https://doi.org/10.1111/nph.14982

Peeler, J.L., and E.S. Menges. 2018. Effects of fire history, tree age, and canopy seed bank size on serotiny of Ocala sand pine (Pinus clausa var. clausa) in Florida scrub. Florida Scientist 81: 3-11.

Platt, W.J., G.W. Evans, and M.M. Davis. 1988. Effects of fire season on flowering of forbs and shrubs in longleaf pine forests. Oecologia 76 (3): 353-363. https:// doi.org/10.1007/BF00377029.

Platt, W.J., S.L. Orzell, and M.G. Slocum. 2015. Seasonality of fire weather strongly influences fire regimes in south Florida savanna-grassland landscapes. Plos One 10 (1): e0116952. https://doi.org/10.1371/journal.pone.0116952.

Prestemon, J.P., U. Shankar, A. Ziu, K. Talgo, D. Yang, E.D. Dixon IV, D. McKenzie, and K.L. Abt. 2016. Projecting wildfire area burned in the south-eastern United States, 2011-60. International Journal of Wildland Fire 25 (7): 715-729. https://doi.org/10.1071/WF15124.

Provencher, L., A.R. Litt, D.R. Gordon, H.L. Rodgers, B.J. Herring, K.E.M. Galley, J.P. McAdoo, S.J. McAdoo, N.M. Gobris, and J.L. Hardesty. 2001. Restoration fire and hurricanes in longleaf pine sandhills. Ecological Restoration 19 (2): 92-98. https://doi.org/10.3368/er.19.2.92.

Quintana-Ascencio, P.F., S.M. Koontz, B. Ochocki, V.L. Sclater, F. Lopez-Borghesi, H. Li, and E.S. Menges. 2019. Assessing the role of seed bank, seed dispersal and historical disturbances for the metapopulation persistence of a pyrogenic herb. Journal of Ecology 107 (6): 2760-2771. https://doi.org/10.1111/1365-274 5.13206

Quintana-Ascencio, P.F., S.M. Koontz, S.A. Smith, V. Sclater, A.S. David, and E.S. Menges. 2018. Predicting landscape-level distribution and abundance: integrating demography, fire, elevation, and landscape habitat configuration. Journal of Ecology 106 (6): 2395-2408. https://doi.org/10.1111/1365-2745.12985.

Quintana-Ascencio, P.F., E.S. Menges, and C.W. Weekley. 2003. A fire-explicit population viability analysis of Hypericum cumulicola in Florida rosemary scrub. Conservation Biology 17 (2): 433-449. https://doi.org/10.1046/j.1523-173 9.2003.01431.x.

Reinhart, K.O., and E.S. Menges. 2004. Effects of re-introducing fire to a central Florida sandhill community. Applied Vegetation Science 7 (1): 141-150. https:// doi.org/10.1111/j.1654-109X.2004.tb00604.X.

Robertson, K.M., and T.L. Hmielowski. 2014. Effects of fire frequency and season on resprouting woody plants in southeastern US pine-grassland communities. Oecologia 174 (3): 765-766. https://doi.org/10.1007/s00442013-2823-4.

Russell-Smith, J., P.G. Ryan, and D.C. Cheal. 2002. Fire regimes and the conservation of sandstone heath in monsoonal northern Australia: frequency, interval, patchiness. Biological Conservation 104 (1): 91-106. https://doi.org/1 0.1016/S0006-3207(01)00157-4

Saha, S., A. Catenazzi, and E.S. Menges. 2010. Does time since fire explain plant biomass distribution in the Florida, USA, scrub ecosystem? Fire Ecology 6 (2): 13-25. https://doi.org/10.4996/fireecology.0602013.

Schmalzer, P.A. 2003. Growth and recovery of oak-saw palmetto scrub through ten years after fire. Natural Areas Journal 23: 5-13.

Schmalzer, P.A., and C.R. Hinkle. 1992. Recovery of oak-saw palmetto scrub after fire. Castanea 57: 158-173.

Swain, H. 1998. Archbold Biological Station and the MacArthur Agro-Ecology Research Center. Bulletin of the Ecological Society of America 79: 114-120.

Turner, W.R., D.S. Wilcove, and H.M. Swain. 2006. Assessing the effectiveness of reserve acquisition programs in protecting rare and threatened species. Conservation Biology 20 (6): 1657-1669. https://doi.org/10.1111/j.1523-1739.2 006.00536.x.

Vesk, P.A. and M. Westoby. 2004. Sprouting ability across diverse disturbances and vegetation types worldwide. Journal of Ecology 92: 310-320.

Weekley, C.W., and E.S. Menges. 2003. Species and vegetation responses to prescribed fire in a long-unburned, endemic-rich Lake Wales Ridge scrub. Journal of the Torrey Botanical Society 130 (4): 265-282. https://doi.org/10.23 $07 / 3557545$.

Weekley, C.W., E.S. Menges, and R.L. Pickert. 2008. An ecological map of Florida's Lake Wales Ridge: A new boundary delineation and an assessment of postColumbian habitat loss. Florida Scientist 71: 45-64.

Willcox, E.V. and W.M. Giuliano. 2010. Seasonal effects of prescribed burning and roller chopping on saw palmetto in flatwoods. Forest Ecology and Management 259: 1580-1585.

Wright, B.R., and P.J. Clarke. 2007. Resprouting responses of Acacia shrubs in the Western Desert of Australia - fire severity, interval and season influence survival. International Journal of Wildland Fire 16 (3): 317-323. https://doi. org/10.1071/WF06094.

Wunderlin, R. P., B. F. Hansen, A. R. Franck, and F. B. Essig. 2020. Atlas of Florida. http://florida.plantatlas.usf.edu/. Accessed 18 May 2020.

Young, A.M., P.E. Higuera, P.A. Duffy, and F.S. Hu. 2017. Climatic thresholds shape northern high-latitude fire regimes and imply vulnerability to future climate change. Ecography 40 (5): 606-617. https://doi.org/10.1111/ecog.02205.

\section{Publisher's Note}

Springer Nature remains neutral with regard to jurisdictional claims in published maps and institutional affiliations. 